Review Article

\title{
Hematological Abnormalities in COVID-19: A Narrative Review
}

\author{
Asma Rahman, ${ }^{1}$ Roshan Niloofa, ${ }^{2}$ Umesh Jayarajah, ${ }^{3}$ Sanjay De Mel, ${ }^{4,5}$ Visula Abeysuriya, ${ }^{5}$ and Suranjith L. Seneviratne ${ }^{5 *}$ \\ ${ }^{1}$ Faculty of Medicine, University of Colombo, Colombo, Sri Lanka; ${ }^{2}$ Department of Zoology and Environment Sciences, Faculty of Science, \\ University of Colombo, Colombo, Sri Lanka; ${ }^{3}$ Postgraduate Institute of Medicine, University of Colombo, Colombo, Sri Lanka; ${ }^{4}$ Department of \\ Haematology-Oncology, National University Cancer Institute, National University Health System Singapore, Singapore, Singapore; ${ }^{5}$ Nawaloka \\ Hospital Research and Education Foundation, Nawaloka Hospitals, Colombo, Sri Lanka
}

\begin{abstract}
COVID-19 is caused by SARS-CoV-2. Although pulmonary manifestations have been identified as the major symptoms, several hematological abnormalities have also been identified. This review summarizes the reported hematological abnormalities (changes in platelet, white blood cell, and hemoglobin, and coagulation/fibrinolytic alterations), explores their patho-mechanisms, and discusses its management. Common hematological abnormalities in COVID-19 are lymphopenia, thrombocytopenia, and elevated $D$-dimer levels. These alterations are significantly more common/ prominent in patients with severe COVID-19 disease, and thus may serve as a possible biomarker for those needing hospitalization and intensive care unit care. Close attention needs to be paid to coagulation abnormalities, and steps should be taken to prevent these occurring or to mitigate their harmful effects. The effect of COVID-19 in patients with hematological abnormalities and recognized hematological drug toxicities of therapies for COVID-19 are also outlined.
\end{abstract}

\section{INTRODUCTION}

COVID-19 is caused by SARS-CoV-2. It is currently a pandemic, and as of December 2, 2020, there have been more than 64 million cases worldwide and less than 1.5 million deaths. ${ }^{1}$ Moreover, this has resulted in a significant impact on healthcare systems, socioeconomic aspects, and the livelihoods of many. ${ }^{1-4}$ Common symptoms of COVID-19 include fever, dry cough, and tiredness. ${ }^{5,6}$ A subset of patients develops a more severe form of disease, characterized by acute respiratory distress syndrome (ARDS), and hematological, neurological, cardiac, and renal complications. ${ }^{7-9}$ Many hematological findings have been reported in COVID19 patients, and this review summarizes the reported hematological abnormalities (changes in platelet, white blood cell, and hemoglobin levels, and coagulation/fibrinolytic alterations), explores their patho-mechanisms, and discusses its management. The effect of COVID-19 in patients with hematological abnormalities and recognized hematological drug toxicities of therapies for COVID-19 are also outlined.

\section{LITERATURE SEARCH}

A literature search was performed using the PubMed, Embase, and Google Scholar databases to identify studies on hematological findings of COVID-19 up to November 30, 2020. The keywords used in the search were as follows: SARS-CoV-2, COVID-19, clinical findings, laboratory findings, hematology, and coagulation. The initial selection was based on the article title and abstract, following which the full-text article was read. The reference lists in the full-text articles were scanned to obtain additional references. Articles relevant to the topic were included, after removing duplicates. The findings from primary research articles, case reports, and case series are summarized and discussed.

\footnotetext{
*Address correspondence to Suranjith L. Seneviratne, Nawaloka Hospital Research and Education Foundation, Nawaloka Hospitals, HK Dharmadasa Mawatha, Colombo, Sri Lanka. E-mail: suran200@ yahoo.co.uk
}

\section{HEMATOLOGICAL ABNORMALITIES IN OTHER CORONAVIRUSES}

Lymphopenia (69.6-100\%) and thrombocytopenia (20-55\%) have been reported in patients with SARS-CoV-1 infections. ${ }^{10}$ The corresponding rates in Middle East respiratory syndrome coronavirus (MERS-CoV) infections were as follows: lymphopenia (44-60\%) and thrombocytopenia (31-40\%). ${ }^{11}$ Lymphopenia is not a prominent finding in coronavirus OC43 and 229E infections that cause common cold-like symptoms. ${ }^{12}$ Several studies found coagulation abnormalities (elevated $D$-dimer level and raised prothrombin time) following SARS-CoV-1 and MERS-CoV infections. For instance, $45 \%$ of SARS-CoV-1 patients had elevated $D$-dimer levels. ${ }^{13}$ Deep vein and multi-organ (including pulmonary and bronchial) thrombosis have been reported in autopsy studies of SARS-CoV-1 infections. ${ }^{14}$ Middle East respiratory syndrome-induced disseminated intravascular coagulation (DIC) was observed in fatal cases. ${ }^{15}$ It is noteworthy that coagulation abnormalities are a feature of the human coronaviruses that cause severe respiratory manifestations and not of all human coronaviruses.

\section{THROMBOCYTOPENIA IN COVID-19}

Thrombocytopenia has been reported in 5-21\% of COVID19 patients (Table 1). In a meta-analysis performed early in the pandemic, significant thrombocytopenia was reported in patients with more severe than mild disease. ${ }^{16}$ Both the metaanalysis and another study (where the median platelet count was $79 \times 10^{9} / \mathrm{L}$ ) found a higher risk of mortality in patients with thrombocytopenia. ${ }^{17}$ Liu et al. ${ }^{18}$ studied the dynamic changes in platelet counts among hospitalized patients and suggested that monitoring such counts may have a role in prognosis. A platelet count $<200 \times 10^{9} / \mathrm{L}$ at admission was associated with three times higher mortality. The degree of thrombocytopenia seen in COVID-19 is generally mild. This contrasts with some other viral diseases such as dengue, where platelet counts may decrease to $<25 \times 10^{9} / \mathrm{L}^{19,20}$

Qu et al. ${ }^{21}$ and Yang et al. ${ }^{22}$ found an elevated plateletlymphocyte ratio (PLR) to be a prognostic marker in 
TABLE 1

Hematological abnormalities in COVID-19

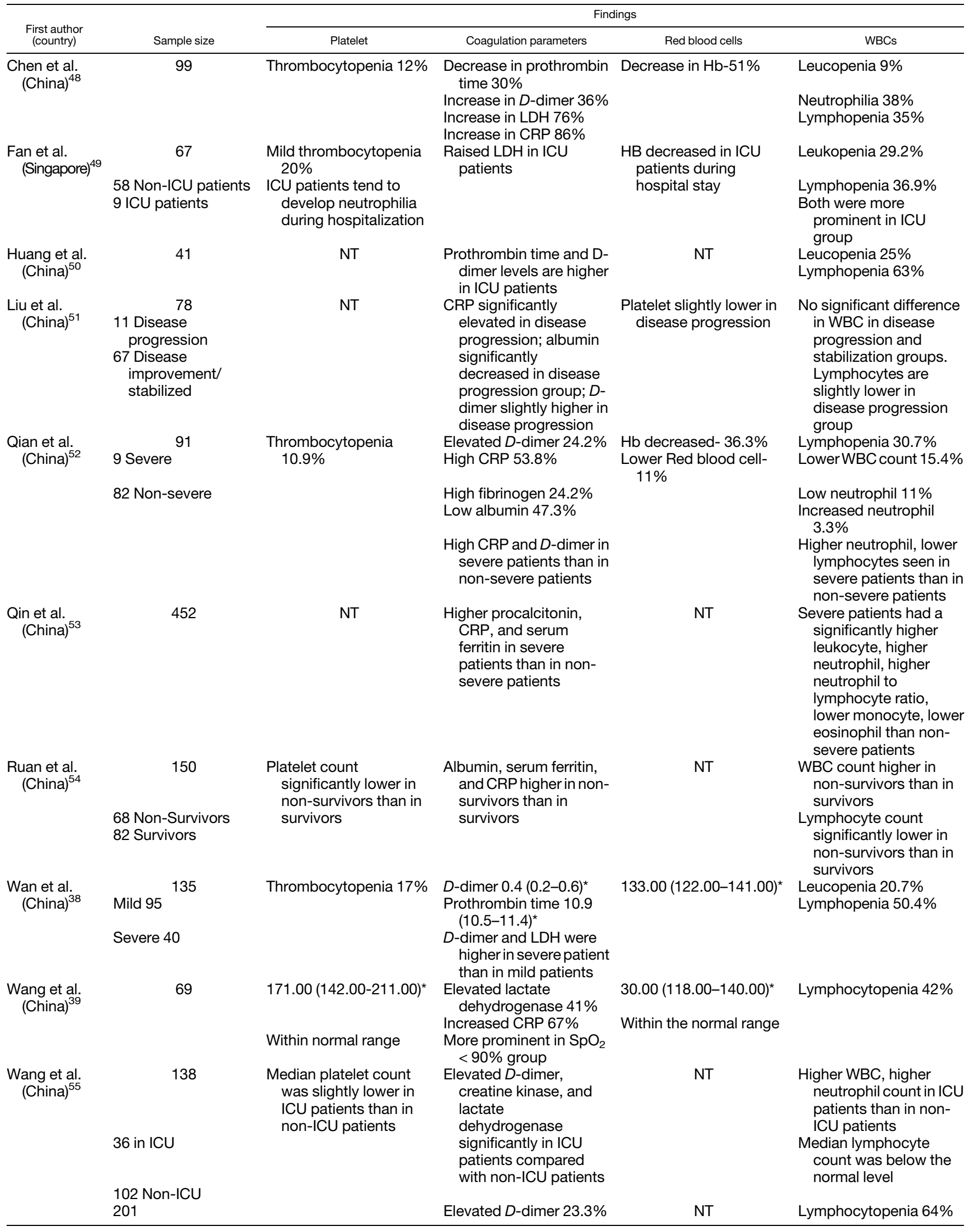


TABLE 1

Continued

\begin{tabular}{|c|c|c|c|c|c|}
\hline \multirow{2}{*}{$\begin{array}{l}\text { First author } \\
\text { (country) }\end{array}$} & \multirow[b]{2}{*}{ Sample size } & \multicolumn{4}{|c|}{ Findings } \\
\hline & & Platelet & Coagulation parameters & Red blood cells & WBCs \\
\hline \multirow[t]{3}{*}{$\begin{array}{l}\text { Wu et al. } \\
\text { (China) })^{56}\end{array}$} & & $\begin{array}{l}\text { Thrombocytopenia } \\
\quad 18.8 \%\end{array}$ & $\begin{array}{l}\text { Significantly elevated for } \\
\text { patients with ARDS }\end{array}$ & & $\begin{array}{l}\text { Significantly decreased } \\
\text { for patients with ARDS }\end{array}$ \\
\hline & & & $\begin{array}{l}\text { Prolonged prothrombin } \\
\text { time } 2.1 \%\end{array}$ & & Leukocytosis $23.4 \%$ \\
\hline & & & Elevated CRP 85.6\% & & $\begin{array}{l}\text { Neutrophilia } 34.5 \% \\
\text { Monocyte elevated } 9.1 \%\end{array}$ \\
\hline $\begin{array}{l}\text { Xu et al. } \\
\text { (China) }^{57}\end{array}$ & 90 & NT & Increased CRC $42 \%$ & NT & $\begin{array}{l}\text { Leucopenia } 21 \% \\
\text { Leukocytosis 3\% }\end{array}$ \\
\hline $\begin{array}{l}\text { Yang et al. } \\
\text { (China) }^{58}\end{array}$ & $\begin{array}{l}52 \text { Critically ill } \\
20 \text { Survivors } \\
32 \text { Non-survivors }\end{array}$ & $\begin{array}{l}\text { Median platelet count } \\
\text { was normal in } \\
\text { survivors and non- } \\
\text { survivors }\end{array}$ & $\begin{array}{l}\text { Prothrombin time slightly } \\
\text { higher in non-survivors } \\
\text { than in survivors }\end{array}$ & NT & $\begin{array}{l}\text { Lymphocytopenia } 85 \% \\
\text { No association between } \\
\text { survivors and non- } \\
\text { survivors }\end{array}$ \\
\hline $\begin{array}{l}\text { Zachariah } \\
\text { et al. (USA) } \\
59\end{array}$ & $\begin{array}{l}\quad 50 \\
\text { 41 Non-severe } \\
9 \text { Severe }\end{array}$ & NT & $\begin{array}{l}\text { Procalcitonin level and } \\
\text { CRP significantly } \\
\text { higher in severe } \\
\text { patients }\end{array}$ & NT & $\begin{array}{l}\text { Lymphopenia } 72 \% \\
\text { Did not significantly differ } \\
\text { between severe and } \\
\text { non-severe patients }\end{array}$ \\
\hline \multirow[t]{3}{*}{$\begin{array}{l}\text { Zhang et al. } \\
{\text { (China) })^{60}}^{\text {(C) }}\end{array}$} & 140 & NT & Elevated $D$-dimer $43.2 \%$ & NT & $\begin{array}{l}\text { Leukocytes decrease } \\
19.6 \%\end{array}$ \\
\hline & 82 Severe & & Elevated CRP 91.9\% & & $\begin{array}{l}\text { Lymphocyte decrease } \\
75.4 \%\end{array}$ \\
\hline & 58 Non-severe & & $\begin{array}{l}\text { Significantly higher } D- \\
\text { dimer and CRP in } \\
\text { severe patients }\end{array}$ & & $\begin{array}{l}\text { Eosinophil lowered } \\
52.9 \% \\
\text { Significantly lower } \\
\text { median value for } \\
\text { leukocytes and } \\
\text { lymphocyte } \\
\text { percentage between } \\
\text { severe and non-severe } \\
\text { patients }\end{array}$ \\
\hline \multirow[t]{2}{*}{$\begin{array}{l}\text { Zhou et al. } \\
\qquad \text { (China) })^{61}\end{array}$} & $\begin{array}{c}191 \\
137 \text { Survivors }\end{array}$ & $\begin{array}{l}\text { Thrombocytopenia } 7 \% \\
\text { More non-survivors } \\
\text { showed } \\
\text { thrombocytopenia } \\
\text { than survivors }\end{array}$ & $\begin{array}{l}\text { Elevated } D \text {-dimer } 32 \% \\
\text { Elevated in non-survivors } \\
\text { compared with } \\
\text { survivors throughout } \\
\text { the clinical course }\end{array}$ & NT & $\begin{array}{l}\text { Lymphocytopenia } 40 \% \\
\text { Leukocytopenia } 17 \%\end{array}$ \\
\hline & 54 Non-survivors & & $\begin{array}{l}\text { High prothrombin time } \\
\quad 6 \%\end{array}$ & & $\begin{array}{l}\text { Non-survivors were } \\
\text { present with lower } \\
\text { leukocytes and } \\
\text { lymphocytes } \\
\text { significantly than } \\
\text { survivors }\end{array}$ \\
\hline
\end{tabular}

*Median (IQR), NT = not tested.

COVID-19. The specificity and sensitivity were 0.44 and 0.77 , respectively, with a cutoff value of $180 .^{22}$ There were some limitations in these studies, as the PLR was not measured at a specified time point in the disease course, and other comorbidities may also affect the PLR. Chan et al. ${ }^{23}$ did a metaanalysis of five studies and found the PLR to be elevated in severe compared with non-severe COVID-19 patients. However, high heterogeneity was seen in the observed PLR values.

Case studies of patients developing idiopathic thrombocytopenia purpura (ITP) and thrombotic thrombocytopenic purpura (TTP) following SARS-CoV-2 infection have been published. ${ }^{24}$ Platelet counts were found to decrease from around day 4 of symptoms. In a systematic review of the COVID19-associated ITP cases, $71 \%$ were older than 50 years and had moderate to severe disease. ${ }^{25}$ Intravenous immunoglobulin and dexamethasone were found to be effective treatment options. ${ }^{25}$ The mechanisms of disease association between COVID-19 and ITP/TTP needs to be further studied.

Ethylenediaminetetraacetic acid (EDTA)-dependent pseudothrombocytopenia is characterized by a spurious decrease of platelets in vitro due to the aggregation of platelets in EDTA anticoagulant blood samples. Some cases of COVID-19related pseudothrombocytopenia have been reported. In one case, the platelet count was normal at admission, but then decreased progressively with no signs of bleeding. As the peripheral blood smear showed platelet aggregation, the platelet count was measured in a blood sample anticoagulated with citrate and was found to be normal. The phenomenon disappeared 17 days later. ${ }^{26}$ In a further case, Kuhlman et al. ${ }^{27}$ describe a patient with panpseudothrombocytopenia associated with an arterial occlusive event leading to death.

\section{COAGULATION ABNORMALITIES IN COVID-19}

A number of studies have reported coagulopathy in patients with COVID-19. This was distinct from other coagulopathies such as DIC. Elevated $D$-dimer levels $\left(>1,000 \mathrm{ng} \cdot \mathrm{mL}^{-1}\right)$ and increased prothrombin times were seen in COVID-19 patients compared with controls (Table 1). Patients with severe disease had higher levels than those with non-severe disease, and thus may serve as a good prognostic marker for identifying 
patients for early therapeutic intervention. ${ }^{28}$ An admission $D$ dimer level $>2.0 \mu \mathrm{g} / \mathrm{mL}$ was able to predict in-hospital mortality in COVID-19 patients. ${ }^{29}$ Three to six times higher rates of thrombosis are noted in COVID-19. ${ }^{28}$

Thrombotic complications are seen in approximately 25-31\% of intensive care unit (ICU)-admitted COVID-19 patients. ${ }^{30,31}$ This includes pulmonary embolism, venous thromboembolic events such as proximal deep vein and upper extremity thrombosis, and arterial thromboembolic events such as ischemic strokes. Lodigiani et al. ${ }^{32}$ analyzed the timing of the arterial and venous thromboembolism (VTE) and found $50 \%$ to be detected within 24 hours of hospital admission. Middeldorp et al. ${ }^{33}$ detected VTE in $20 \%$ of ICU versus $3.3 \%$ of non-ICU COVID-19 patients. The corresponding rates were $50 \%$ versus $18 \%$ in another study. ${ }^{34}$ In a prospective cohort study, Helms et al. ${ }^{35}$ reported a range of thrombotic complications in $42.7 \%$ of COVID-19 patients. Even with the use of anticoagulation, patients with ARDS developed life-threatening thrombotic complications, suggesting the need for further refinements of the anticoagulation regimes. COVID-19 patients admitted to the ICU may have other risk factors (such as old age, obesity, and smoking) that may exacerbate coagulopathy. Clinicians should be aware of coagulopathy-related complications in COVID patients undergoing emergency interventions or surgery. ${ }^{36}$ Understanding coagulation alterations related to COVID-19 is a vital area of further research.

\section{RED CELL AND HEMOGLOBIN ABNORMALITIES IN COVID-19}

Reduced hemoglobin levels have been noted in some severe COVID-19 patients (Table 1) A meta-analysis of four studies found hemoglobin concentrations to be lower in severe disease than in mild infections. ${ }^{37} \mathrm{~A}$ few studies found no significant changes in hemoglobin levels in COVID-19 patients. ${ }^{38,39}$ Although Lippi et al. ${ }^{37}$ suggested monitoring hemoglobin levels to detect poor prognosis, more exploratory studies are needed on this aspect. No significant effects on red blood cell (RBC) counts have been found, but structural changes have been noted. ${ }^{40}$ Red blood cells of COVID-19 patients had increased oxidation of structural proteins and altered lipid metabolism.

\section{WHITE BLOOD CELL ABNORMALITIES IN COVID-19}

Twenty to $40 \%$ of COVID-19 patients have leucopenia, and 3-24\% have leukocytosis (Table 1). Lymphopenia (lymphocyte count $\leq 1,100$ cells $/ \mu \mathrm{L}$ ) was seen in $30-75 \%$ of COVID-19 patients (Table 1). A meta-analysis performed by Huan and Pranata found a strong association between lymphopenia and severe COVID-19. ${ }^{41} \mathrm{CD}^{+}$and $\mathrm{CD} 8^{+} \mathrm{T}$ lymphocytes are predominantly reduced in the COVID-19 patients requiring ICU care. There was increased expression of PD-1 and Tim-3 in surviving $T$ cells, suggesting functional exhaustion. ${ }^{42} \mathrm{Neu}-$ trophilia has been reported in severe COVID-19 patients (Table 1). An elevated neutrophil to lymphocyte ratio was identified as a marker for in-hospital mortality and severe COVID-19 disease. ${ }^{43}$ Reactive lymphocytes have been described in many viral infections including COVID-19. ${ }^{44}$ Reactive lymphocyte and antibody secreting lymphocytes identified based on automated hematology analyzer scattergrams were shown to rise toward the second week of infection. ${ }^{45}$ Although not many studies have commented on changes in eosinophil counts in COVID-19, Zhang et al. ${ }^{46}$ found $52.9 \%$ COVID-19 patients to have reduced eosinophils count.

Zini et al. ${ }^{47}$ found morphological changes in neutrophils (such as abnormal shape of the nucleus and cytoplasmic granulation) and platelets (hyperchromatic forms). Apoptotic and immature granulocytes were observed in the peripheral blood smear and may be due to the perturbation of normal granulopoiesis. The cytokine storm and hyperinflammation were proposed as possible causal factors for these changes. Immature granulocytes (small myelocytes and metamyelocytes) were also observed. Following antiviral treatment, the neutrophil morphology reverted to normal, and lymphocytes showed morphological heterogeneity suggesting activation. Further studies would clarify the clinical relevance of the observed changes.

\section{EFFECTS ON THE BONE MARROW IN COVID-19}

Hemophagocytosis has been noted in the bone marrow aspirates of three severe COVID-19 patients. ${ }^{62}$ There was an increase in pleomorphic megakaryocytes, plasma cells, macrophages, and hemophagocytosis. Rapkiewicz et al. ${ }^{63}$ found increased numbers of megakaryocytes in the bone marrow, with morphology pointing to active platelet production. Rare virions were also identified in bone marrow megakaryocytes using electron microscopy.

\section{EFFECTS ON THE SPLEEN IN COVID-19}

The angiotensin-converting enzyme-2 (ACE-2) receptor is expressed in the spleen, at lower concentrations than in the lung, heart, and intestines. ${ }^{64}$ On postmortem examination of six COVID-19 patients, ACE-2 was found to be expressed in the splenic red pulp and medulla of lymph nodes. ${ }^{65}$ Angiotensin-converting enzyme-2 receptors were also expressed on CD68 and CD169 macrophages in the spleen and lymph nodes. Viral nucleocapsid antigens were predominantly noted in the splenic red pulp and occasionally the white pulp. Virus-infected macrophages may cause lymphocyte apoptosis via production of IL-6. ${ }^{65} \mathrm{Xu}$ et al. ${ }^{66}$ studied the pathological changes in the spleen of 10 COVID-19 patients, and found a decrease in $\mathrm{T}$ and $\mathrm{B}$ lymphocytes, a reduction and atrophy of lymphoid follicles, atrophy of the white pulp, and neutrophil/plasma cell infiltration. Yao et al. ${ }^{67}$ found a reduced number of lymphocytes and cell degeneration/necrosis in the spleen. These may have an impact on immune cells, particularly a decrease in lymphocytes. Studies on COVID-19 on the bone marrow and spleen are summarized in Table 2.

\section{POSTULATED MECHANISMS OF HEMATOLOGICAL ABNORMALITIES IN COVID-19}

Platelets. The potential reasons for thrombocytopenia include direct effect of SARS-CoV-2 on platelet production, autoimmune destruction of platelets, or increased platelet consumption. Secondary hemophagocytic lymphohistiocytosis causes excessive proliferation and activation of macrophages, and in turn produces a surge in inflammatory cytokines. It has been postulated this cytokine storm 
TABLE 2

Studies on SARS-CoV-2 effects of the spleen and bone marrow

\begin{tabular}{|c|c|}
\hline Spleen & \\
\hline Santos Leite Pessoa et al. ${ }^{68}$ & Three cases of splenic infarction as a thrombotic complication in COVID-19 \\
\hline Chen et al. ${ }^{69}$ & $\begin{array}{l}\text { Showed that ACE2 receptor expressed on tissue-resident CD169 + macrophages in the } \\
\text { spleens } \\
\text { SARS-CoV-2 infection induces severe tissue damage such as splenic nodule atrophy }\end{array}$ \\
\hline Li et al. ${ }^{70}$ & $\begin{array}{l}\text { Studied the ACE2 expression in a wide variety of human tissue. ACE2 expression was seen in } \\
\text { the spleen, however, in a low amount }\end{array}$ \\
\hline Xu et al. ${ }^{71}$ & $\begin{array}{l}\text { Pathological changes of the spleen in } 10 \text { patients. T and } B \text { lymphocytes of the spleen are } \\
\text { reduced to varying degrees; the spleen nodules are atrophied, reduced, or absent }\end{array}$ \\
\hline $\begin{array}{l}\text { Bone marrow } \\
\text { Li et al. }^{70}\end{array}$ & $\begin{array}{l}\text { Studied the ACE2 expression in a wide variety of human tissue. Angiotensin-converting } \\
\text { enzyme- } 2 \text { expression was seen in the bone marrow, however, in a low amount }\end{array}$ \\
\hline Ratajczak and Kucia ${ }^{72}$ & $\begin{array}{l}\text { Angiotensin-converting enzyme-2 and the entry-facilitating transmembrane protease } \\
\text { TMPRSS2 are expressed on very small CD133 + CD34 + Lin-CD45- cells in human } \\
\text { umbilical cord blood (UCB), which can be specified into functional hemopoietic stem cells } \\
\text { and endothelial progenitor cells } \\
\text { In human, very small embryonic-like stem cells (VSELs) and HSCs, the interaction of the ACE2 } \\
\text { receptor with the SARS-CoV-2 spike protein activates the NIrp3 inflammasome, which may } \\
\text { lead to cell death } \\
\text { ACE2 expression seen in human mononuclear cells }\end{array}$ \\
\hline & \\
\hline
\end{tabular}

damages hematopoietic progenitors and reduces platelet production. ${ }^{74}$ Antibody-mediated platelet damage has been observed in HIV, ${ }^{75}$ but had previously not been reported with coronavirus infections. However, potential immunemediated platelet destruction needs to be considered in the light of reports of post-COVID ITP and TTP. ${ }^{76,77}$ The likely mechanism in this case is molecular mimicry between the antigens of SARS-CoV-2 and platelet glycoproteins. However, sequence homology between SARS-CoV-2 proteins and platelet antigens is still to be identified. ${ }^{78}$ Molecular mimicry has been previously reported with other viral infections such as hepatitis $C$, where the core-envelope peptides share similarity with a platelet antigen. ${ }^{79}$ Microthrombi formation is common in COVID-19 and may lead to platelet consumption. Platelet-rich thrombi were found in the lungs, heart, and bones, in an autopsy study of seven COVID-19 patients. ${ }^{72}$ Platelets may also be destroyed in the spleen. Figure 1 outlines the possible mechanisms of hematological abnormalities.

Coagulation and fibrinolytic system. Several mechanisms have been postulated for altered coagulation in COVID19. The antiviral inflammatory response may shift the balance in the anticoagulant and procoagulant pathways, leading to altered coagulation. ${ }^{15}$ von Willebrand Factor (VWF) is a procoagulant that is released in the presence of endothelial cell damage and has been found to be elevated in COVID-19. ${ }^{80}$ He et al. ${ }^{81}$ described the COVID-19-pericyte hypothesis, where ACE-2 receptors are present on specific pericytes rather than endothelial cells. Pericytes are located in the basement membranes of capillaries where it is wrapped around endothelial cells. Invasion of pericytes by the SARS-CoV-2 virus may lead to an inflammatory and prothrombotic response. ${ }^{81}$ Further experiments are needed to assess the degree of invasion of pericytes by SARSCoV-2.

Injury due to neutrophil extracellular traps (NETs) may be a factor for thrombosis. Excess neutrophil infiltration to the alveolar space (associated with acute capillaritis) was observed in three autopsy cases of COVID-19. ${ }^{82}$ Targeting NETs may be a potential therapeutic option for preventing and controlling the thrombotic tendency, and further research in the area should be undertaken. There is evidence that activation of different complement pathways may lead to activation of the coagulation system. ${ }^{83}$ This may be due to an increase of platelet activity/aggregation, increase of prothrombinase and tissue factor activity, and the stimulation of endothelial cells to release VWF. Studies have described the over-activation of the complement system in COVID-19, and this in-turn may account for the observed hypercoagulable state.

Red blood cells and hemoglobin. Using a bioinformatics approach, Liu and $\mathrm{Li}^{84}$ proposed certain SARS-CoV-2 proteins may attack the beta chain of hemoglobin, thus reducing its level. A reduction in hemoglobin (and thus oxygen content) may explain some of the symptoms of respiratory distress. Experimental confirmation of these bioinformatics findings would be needed.

White blood cells. The presently favored explanation for lymphopenia is invasion of lymphocytes by the virus, as ACE2 receptors are found on lymphocytes. ${ }^{85}$ The virus may directly attack lymphocytes causing apoptosis, invade bone marrow cells, or cause destruction of the spleen or lymph nodes. Raised lactic acid levels in COVID-19 may lead to reduced lymphocyte proliferation. ${ }^{86}$ The cytokine storm may adversely impact T-cell numbers and function. ${ }^{42}$ Neutrophilia may be due to viral-induced inflammation or due to secondary bacterial infections (seen in approximately 10\% of COVID-19 patients). ${ }^{50}$

Bone marrow. The ACE2 receptor has been found to be expressed in the bone marrow, ${ }^{70}$ including hematopoietic stem cells. ${ }^{87,88}$ Direct viral effects on the hematopoietic stem cells may affect hematopoiesis. Similar effects are observed in HIV, as receptors of HIV are expressed in hematopoietic stem cells (HSCs). ${ }^{89}$ Abnormalities in platelet and lymphocyte counts and function may at least in part be due to this mechanism. Ratajczak and Kucia ${ }^{72}$ have postulated a role for the nucleotide-binding domain (NOD)-like receptor protein 3 (NIrp3) inflammasome expressed in hematopoietic stem cells for the abnormalities of hematopoiesis. Activation of the Nirp3 inflammasome may exacerbate the observed cytokine storm. 


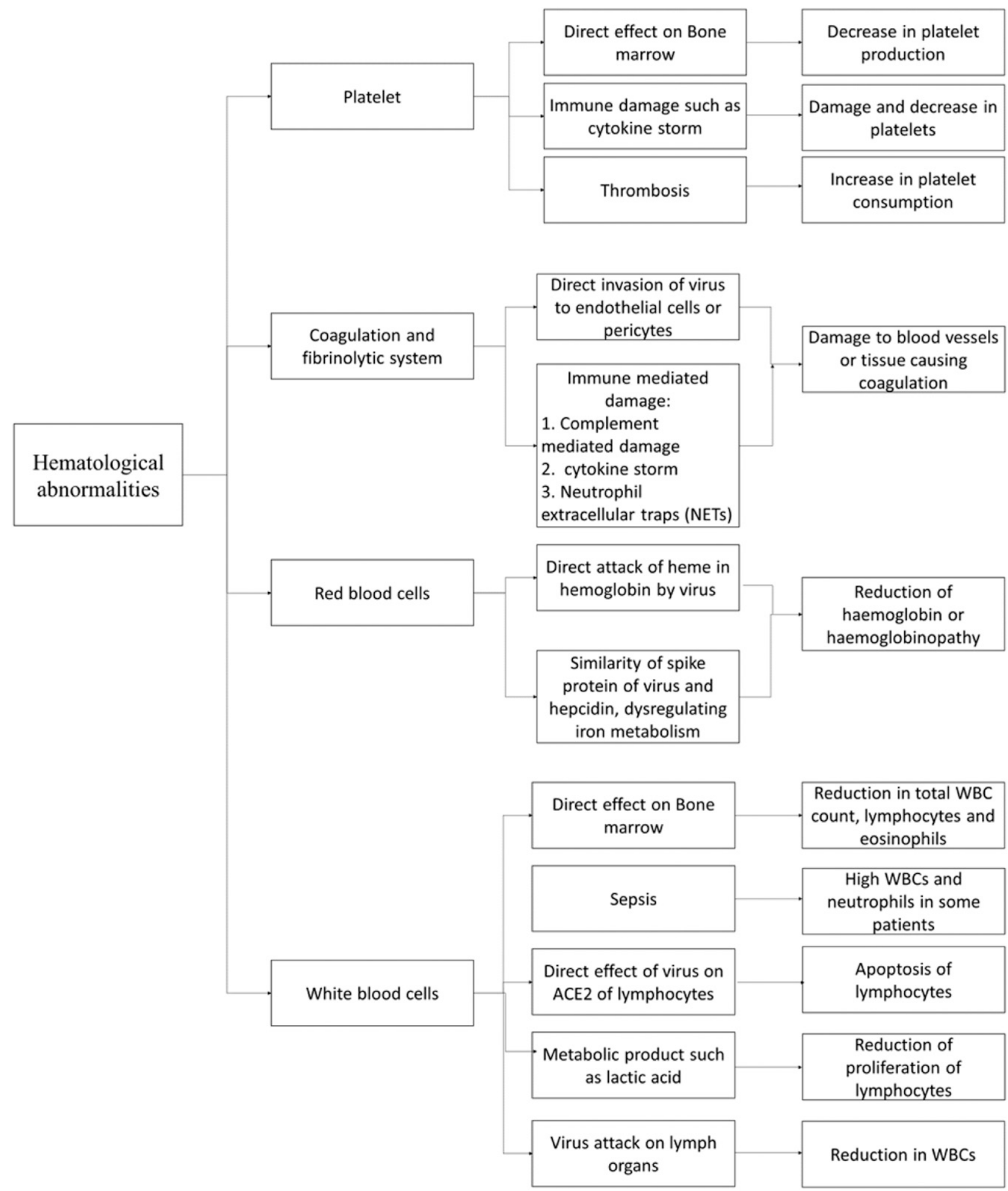

FIGURE 1. Mechanisms of hematological abnormalities in COVID-19.

\section{COVID-19 INFECTIONS IN PATIENTS WITH HEMATOLOGICAL DISORDERS}

Red blood cell disorders. In general, patients with sickle cell disease (SCD) and thalassemia have a higher risk for developing infections (especially respiratory tract infections).
Hydroxycarbamide, a commonly used medication in SCD, has immunosuppressive actions, and needs extra care when used..$^{90} \mathrm{~A}$ small study on 11 thalassemia patients did not find an increased severity of COVID-19. ${ }^{11}$ Using multiple regression analysis, it has been hypothesized that patients with heterozygous beta-thalassemia may be protected against 
COVID-19. ${ }^{92}$ However, this analysis relied solely on statistical methods and used a simulated COVID-19 tracker. Patients with red blood cell disorders are advised to strictly follow practices for avoiding SARS-CoV-2 infections.

Bleeding and coagulation disorders. At present, large cohort studies are lacking on patients with bleeding and coagulation disorders getting COVID-19. In a hemophilia patient, the COVID-19 clinical manifestations were similar to other patients, and there were no bleeding events. ${ }^{93}$ It is not certain if patients with idiopathic ITP or TTP are at increased risk of COVID-19 or if they would get more severe disease. If the patient is receiving immunosuppressive drugs, extra care may be advisable.

Hematological cancers. As hematologic malignancies directly affect the immune system, these patients are at significantly higher risk of a variety of severe infections including COVID-19. ${ }^{94}$ Patients with hematologic malignancies often receive myelosuppressive chemotherapy which further increases their risk of infections. ${ }^{95}$

Impact of COVID-19 on clinical outcomes in patients with hematologic malignancies. Several factors may influence outcomes in patients with hematologic malignancies. Direct immunosuppressive effects and therapeutic side effects such as myelosuppression and lymphodepletion may make such patients more prone to infections. ${ }^{94}$ An Italian study found high mortality in hematologic malignancy patients with COVID-19 infection when compared with those with a hematologic malignancy alone. ${ }^{96} \mathrm{~A}$ study conducted at two centers in Wuhan, China, among hematologic malignancy patients found no differences in baseline characteristics between subjects who did or did not develop COVID-19. However, the hematologic malignancy patients with COVID-19 had higher mortality than those without COVID-19. ${ }^{97}$

A multicenter study found patients with hematologic, lung, or metastatic (stage IV) cancer had more severe disease than those without malignancy. ${ }^{98}$ Jose Luis and team concluded that in patients with hematologic malignancies and COVID-19, mortality was directly associated with older age, disease status, performance status, immune parameters, and levels of inflammation, and the use of azithromycin and low dose corticosteroids may be beneficial. ${ }^{99}$ In addition, Julio Garcia and others concluded that in patients with hematologic malignancies and COVID-19, death was associated with higher age, comorbidities, type of hematologic malignancy, and class of antineoplastic therapy. ${ }^{100}$ Lattenist and others found patients with hematologic malignancies to be vulnerable to SARSCoV-2, with age and low hemoglobin levels to be risk factors for poor outcome. ${ }^{101}$ In one study, elderly patients (age > 65 years) with hematologic cancers did not have an increased risk of death following COVID-19. ${ }^{102}$

Impact of COVID-19 on hematologic malignancy clinical services. Prevention of infections is a crucial part of the management of hematologic cancer patients. During the pandemic, clinicians have had to rethink and remodel the provision of curative care for such patients. Schrag et al. ${ }^{103}$ suggested that although appropriate therapy is continuing, physicians should take steps to reduce the risk from COVID19 , such as the selection of oral over intravenous treatment regimens wherever there is equipoise, the more judicious use of growth factor support, and reducing surveillance laboratory and radiologic evaluations when possible. Shirke et al. suggested the use of tele-oncology services to reduce the risk of cancer patients being exposed to the SARS-CoV-2 virus. ${ }^{104}$ Humaid and team suggested the need for clear communication and education about hand hygiene, infection control measures, high-risk exposure, and awareness on signs and symptoms of SARS-CoV-2. They also suggested the need to individually evaluate the necessity of active intervention, postponing elective surgery or adjuvant chemotherapy for patients with low risk of progression, and minimizing outpatient visits for mitigating exposure and transmission. ${ }^{105}$

Optimal protection of healthcare staff is important during the pandemic. Rapid response by institutions, adjustments to organizational structure, strategic planning, developing and implementing effective guidelines, and providing effective and alternative ways to protect and support clinical staff and employees and patients are key to achieve good care during the pandemic. ${ }^{106}$ Many hematologic malignancy patients rely on clinical trials to receive their care, but during the pandemic, the conduct of several clinical trials has been affected. ${ }^{107}$ The risk of adverse events from cancer therapies is unlikely to be increased. ${ }^{108}$ Hematological malignancy units should be SARSCoV-2-free zones, dedicated solely to hematologic treatment. Patients should strictly comply with social distancing, and hospital outpatient visits should be reduced. ${ }^{109}$

Lee et al. ${ }^{110}$ studied mortality patterns from COVID-19 in cancer patients $(8 \%$ and $14 \%$ had lymphomas and hematological malignancies, respectively) and found no increased risk of death. On the other hand, He et al. ${ }^{97}$ studied 13 patients with hematological cancers (acute myeloid leukemia, acute lymphoblastic leukemia, plasma cell myeloma, and myelodysplastic syndromes) who developed COVID-19, and found more severe disease and a higher case fatality rate than other hospitalized patients. The higher case fatality rates may be attributed to the therapy they were receiving or due to other comorbid conditions such as diabetes, which is common in this group of patients. There was no association between the type of cancer and risk of developing COVID-19. In another study on cancer patients $(8.6 \%$ had hematological cancers-leukemia, myeloma, and lymphoma) with SARS-CoV-2 infections, those with hematological cancers had the highest severity and death rate (33\%). ${ }^{98}$ This may be because patients with hematological cancers receive more immunosuppression than those with solid tumors. ${ }^{109}$

\section{ABO BLOOD GROUPS AND COVID-19}

A number of studies have suggested an association between $\mathrm{ABO}$ blood groups and SARS-CoV-2 infection risk, with group $\mathrm{O}$ individuals having a lower risk. Multiple single nucleotide polymorphisms were examined in a genome-wide association study on severe COVID-19 patients. Significant associations were found with single nucleotide polymorphism on chromosome 3p21.31 and 9q34.2. Interestingly, the chromosome nine association was linked to the ABO locus. ${ }^{111}$

\section{TRANSFUSION AND COVID-19}

The requirement of transfusions is low in patients with COVID-19 including severe cases. ${ }^{112}$ In a retrospective study by Barriteau et al., ${ }^{113} 13.4 \%$ hospitalized COVID-19 patients received transfusions, of which $11 \%$ received $\mathrm{RBC}$ and less than $2 \%$ received each of the other components such as 
platelets or plasma. This study showed that hospitalized COVID-19 patients had a lower requirement for transfusions than other hospitalized patients. The pandemic has impacted blood donations due to lockdowns in certain areas and safety concerns. Corman et al. ${ }^{114}$ assessed the risk of transfusionrelated transmission by testing for SARS-CoV-2 virus in the blood of 18 symptomatic and asymptomatic patients. RNA was not detected; however, the study should be conducted in larger numbers of patients to explore this further.

\section{MANAGEMENT OF HEMATOLOGICAL ABNORMALITIES IN COVID-19}

Platelets. As severe thrombocytopenia is not common in COVID-19 patients, treatment of this aspect is usually not needed. There are some case reports of patients with COVID19, who developed ITP or TTP, and all of them had favorable outcomes. $^{24,115,116}$

Coagulation and fibrinolytic system. The routine use of antithrombotic prophylaxis with low-molecular-weight heparin is recommended for inpatients by the International Society on Thrombosis and Hemostasis. ${ }^{117}$ Moreover, the role of heparin as an anti-inflammatory agent is of additional benefit in patients with COVID-19. ${ }^{118}$ However, severe COVID-19 infections may be complicated by liver dysfunction which may worsen the coagulopathy and increase the risk of bleeding. Therefore, the dose and the type of anticoagulants should be adjusted based on the clinical severity of the disease and associated organ impairment. ${ }^{117}$ Higher doses in obese patients were shown to be necessary. In a study by Wang et al., ${ }^{119}$ in those with higher body mass index $\left(>40 \mathrm{kgm}^{-2}\right)$, a higher antithrombotic prophylaxis dose decreased the odds of symptomatic venous thrombosis by $50 \%$.

There is increasing debate over antithrombotic prophylaxis post-discharge. During the 6 -week post-discharge period, 4.8/1,000 discharges were associated with VTE. However, the odds were not significantly higher than hospitalization for other acute medical illnesses. Therefore, the role of routine post-discharge thromboprophylaxis remains uncertain. ${ }^{120}$

The treatment with a full dose of anticoagulation may be beneficial for patients with sepsis-induced coagulopathy (SIC). ${ }^{121}$ In a retrospective study by Tang et al., ${ }^{122}$ the use of heparin was shown to reduce mortality in patients who met the SIC criteria or had a markedly increased $D$-dimer levels. In patients with a thromboembolic event or an increased suspicion for thromboembolic disease, therapeutic anticoagulation is recommended. ${ }^{123}$ Furthermore, therapeutic anticoagulation should be considered in patients on continuous renal replacement therapy, extracorporeal membrane oxygenation, or diagnosed thrombosis of extracorporeal filters or catheters. ${ }^{120}$ Heparin resistance has been reported among critically ill COVID patients. In such patients, anti-factor Xa levels may be of use to guide therapy. ${ }^{124}$

Importantly, greater than $50 \%$ of VTE were diagnosed on the first day of admission, emphasizing the need for early detection and management. ${ }^{32}$ However, routine screening is not practical in the context of a pandemic and, therefore, not recommended. ${ }^{125}$ The need for imaging is assessed based on clinical grounds. ${ }^{121}$ As an alternative to sophisticated imaging modalities, bedside ultrasound has been used with acceptable sensitivity (100\%) and specificity (95.8\%) in the diagnosis of VTE. ${ }^{124}$ Bedside cardiac ultrasonography may suggest a diagnosis of pulmonary embolism based on the analysis of right ventricular function in clinically suspicious patients. ${ }^{121}$

Patients on warfarin should be converted to other anticoagulants such as heparin, as close monitoring of international normalized ratio would be difficult during isolation for COVID19. ${ }^{121}$ Low molecular weight heparin (LMWH) would be preferred over unfractionated heparin, as the need for regular monitoring is lower. The patients may be transitioned to direct oral anticoagulants if they are able to tolerate oral intake. However, clinicians should be aware of possible drug interactions with antivirals such as ritonavir, lopinavir, or darunavir, and anti-IL-6 such as tocilizumab which may be used for treatment of COVID-19 infections. Moreover, in the context of critical infection with associated renal impairment, decreased excretion of direct oral anticoagulants may increase the risk of bleeding. ${ }^{125}$ Therefore, direct oral anticoagulants are best avoided in the critically ill.

Several clinical trials are underway on the use of anticoagulants in patients with COVID-19. Anticoagulants should be given carefully in patients with some hematological disorders such as hemophilia and von Willebrand disorder. $D$-dimer has no utility in the diagnosis of VTE; it has a poor positive predictive value but a high negative predictive value so may be used to exclude pulmonary embolism (PE) in patients with a low clinical suspicion. Thachil et al. ${ }^{126}$ have suggested thromboprophylaxis for patients requiring hospital admission with a view to reducing poor outcomes. Further well-designed clinical trials on thromboprophylaxis would be helpful. Table 3 summarizes the studies using anticoagulation.

Red blood cells. Although anemia has been reported in some patients, no studies have shown transfusion support for this indication alone, to improve outcomes. Patients with hemoglobinopathies and COVID-19 should continue to receive transfusions and chelation therapy as needed. ${ }^{90}$

White blood cells. The use of corticosteroids for reducing COVID-19-related inflammation has been studied. The RECOVERY trial gained much attention when it found an 8-26\% lower mortality among patients who received $6 \mathrm{mg} /$ day of dexamethasone for up to 10 days. ${ }^{134}$ Several clinical trials on the use of mesenchymal stem cells (MSCs) as therapy for COVID-19 are undergoing. Leng et al. ${ }^{135}$ treated seven patients with MSCs and observed an increase in the lymphocyte count and a decrease in C-reactive protein (CRP) and cytokine secreting $T$ and natural killer cells within 3-6 days. However, the cost of such procedures and the prolonged time period needed for gaining treatment approval are factors that need to be considered.

\section{CONVALESCENT BLOOD PRODUCT THERAPY IN COVID-19}

Convalescent blood product (CBP) therapy is a promising treatment option. In the systemic review of five studies (and 27 patients), Rajendran et al. ${ }^{136}$ found a positive outcome for CBP therapy. A reduced viral load and an increase in neutralizing antibody titers were noted. An increased transfusiontransmitted infections and other blood product-related adverse reactions are possibilities, but CBP therapy was otherwise well tolerated.

A study by Salazar et al. ${ }^{137}$ including 25 severe or lifethreatening SARS-CoV-2 patients who were administered CBPs documented uneventful recovery. The average length of 


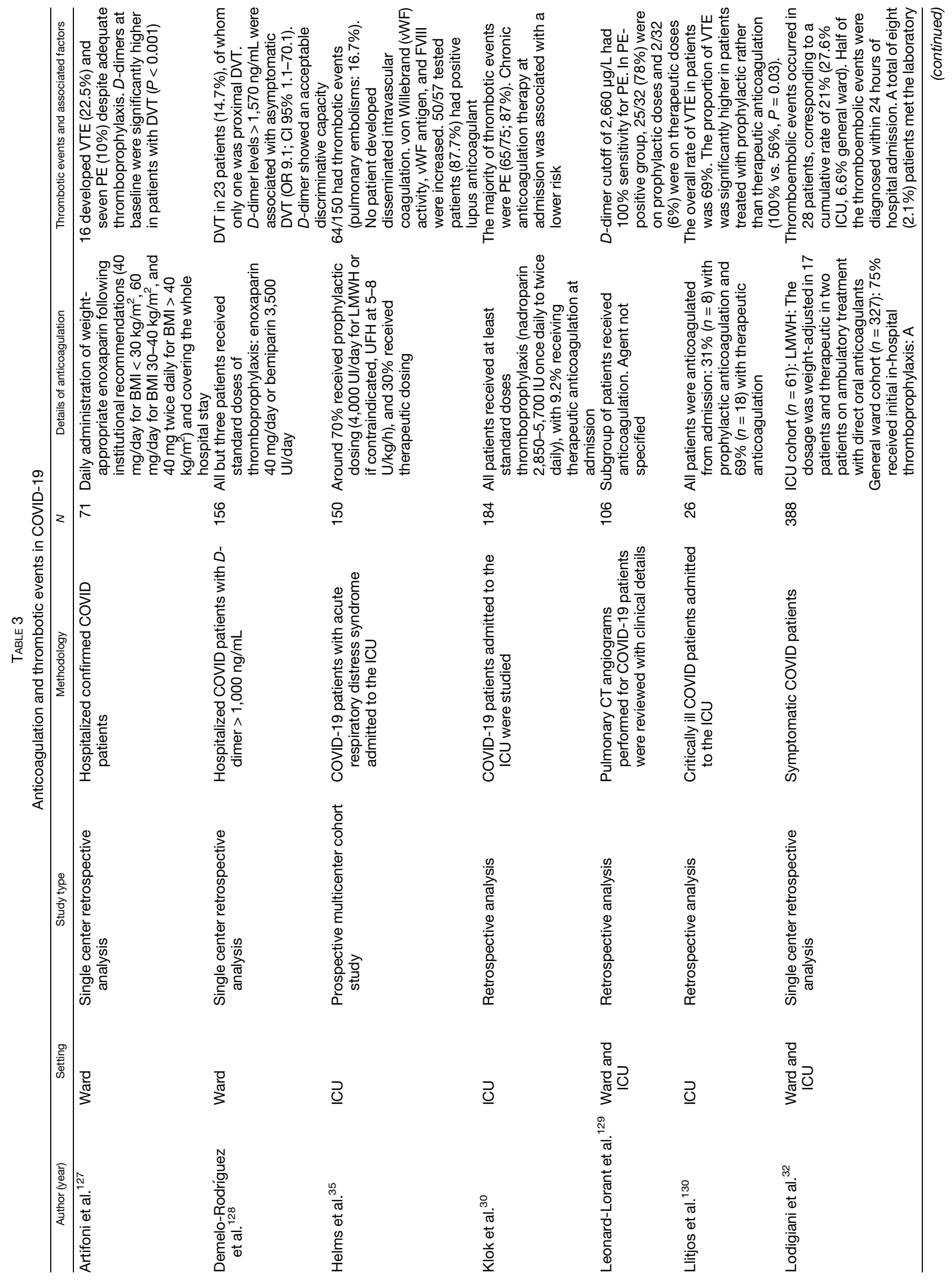




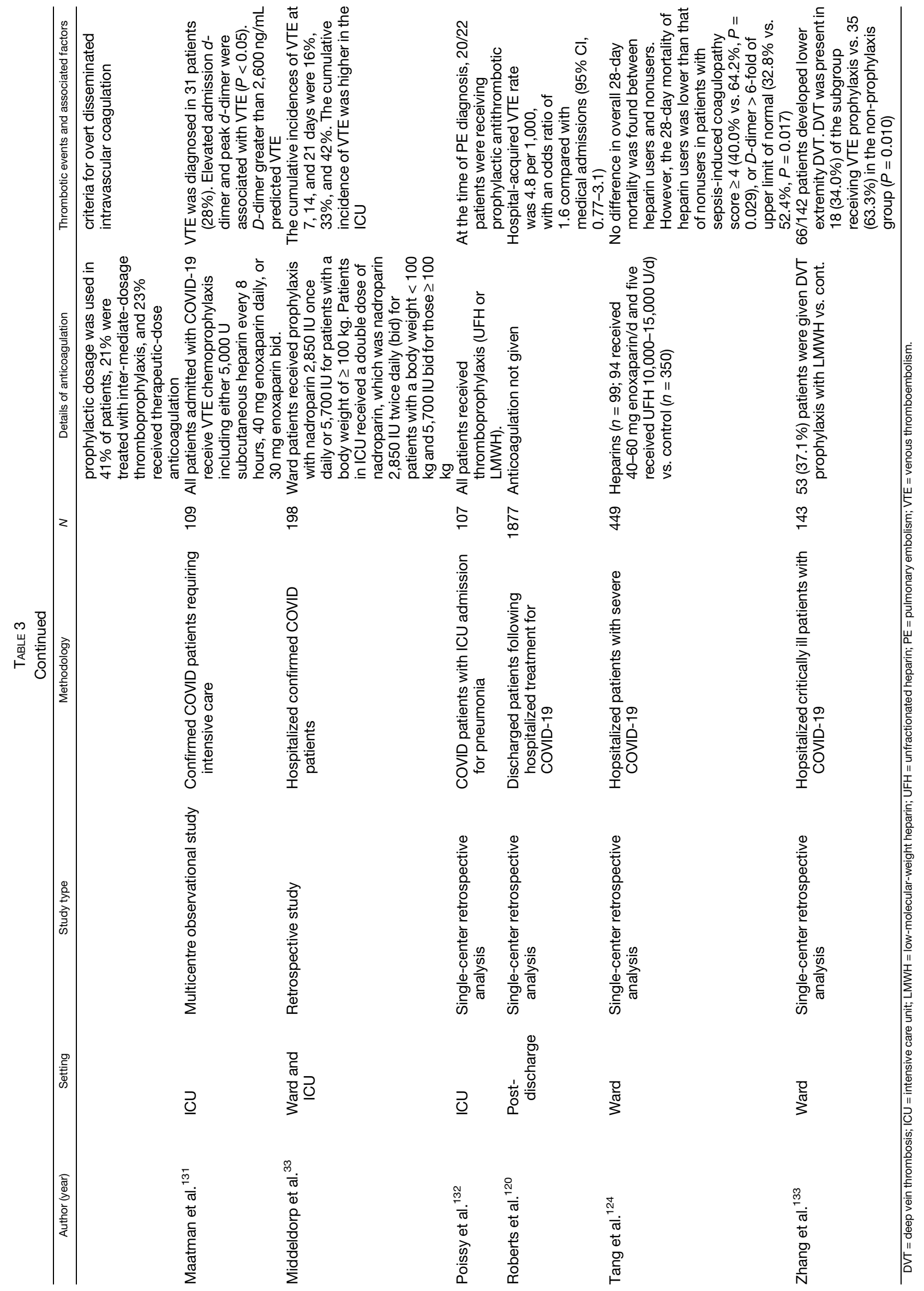


hospital stay and posttransfusion length of stay were 14.3 days and 11 days, respectively, and there were no significant adverse events. However, patients were concomitantly receiving other treatment such as antivirals, steroids, and immunomodulators. Therefore, the study did not provide satisfactory data because of other confounding factors.

A multicenter open-label randomized control study using a stratified sampling technique based on disease severity showed no improvement in the group that received convalescent products compared with the control group. ${ }^{138} \mathrm{How}-$ ever, it was shown to be safe with minimal adverse effects. Although CBPs may be useful as a monotherapy or combination with other drugs, there is a lack of robust evidence showing convincing results. Furthermore, data regarding the optimal time of administration, the dosage, and the optimal antibody titer are not available. Therefore, future prospective studies are needed. Furthermore, monoclonal antibody therapy has been used as prophylaxis for COVID-19, and studies are ongoing for identifying and purifying therapeutic neutralizing antibodies. ${ }^{139}$

\section{POSSIBLE HEMATOLOGICAL EFFECTS OF THERAPIES USED FOR COVID-19}

The positive and negative hematological effects of medications used to treat COVID-19 are under review. The role of favipiravir and remdesivir in COVID-19 has been studied. ${ }^{140,141}$ Clinicians need to be mindful of potential drug interactions that may exacerbate coagulopathy. An increase in prothrombin time was observed in $<5 \%$ of patients receiving remdesivir. ${ }^{142}$

\section{HEMATOLOGICAL ABNORMALITIES AND SEVERITY OF COVID-19}

Lymphocytopenia is significantly more common in patients with severe COVID-19. Non-survivors had a lower lymphocyte count and higher prothrombin time than survivors. ${ }^{142,143}$ Antibody synthesizing lymphocytes as a percentage of total lymphocytes were also shown to be predictive of severe disease. ${ }^{45} D$-dimer level is the most useful and consistent marker for identifying COVID-19 disease severity. Yao et al. ${ }^{144}$ found a $D$-dimer level of $>2.14 \mathrm{mg} / \mathrm{L}$ to predict hospital mortality, with a sensitivity of $88.2 \%$ and specificity of $71.3 \%$.

\section{CONCLUSION}

Common hematological abnormalities in COVID-19 are lymphopenia, thrombocytopenia, and elevated $D$-dimer and CRP levels. These alterations are significantly more common/ prominent in patients with severe COVID-19 disease, and thus may serve as a possible biomarker for those needing hospitalization and ICU care. As performing complex tests for identification of coagulation abnormalities is not practical in a pandemic setting, the use of serial $D$-dimer levels may be considered in view of practical clinical decisions. Close attention needs to be paid to coagulation abnormalities and steps taken to prevent these occurring or to mitigate their harmful effects.

Received December 3, 2020. Accepted for publication February 8, 2021.
Published online February 19, 2021.

Acknowledgments: The American Society of Tropical Medicine and Hygiene has waived the Open Access fee for this article due to the ongoing COVID-19 pandemic and has assisted with publication expenses.

Authors' addresses: Asma Rahman, Faculty of Medicine, University of Colombo, Colombo, Sri Lanka, E-mail: asma.rahman28@gmail.com. Roshan Niloofa, Department of Zoology and Environment Sciences, Faculty of Science, University of Colombo, Colombo, Sri Lanka, E-mail: rosh86niloo@gmail.com. Umesh Jayarajah, Postgraduate Institute of Medicine, University of Colombo, Colombo, Sri Lanka, E-mail: umeshe.jaya@gmail.com. Sanjay De Mel, Department of Haematology- Oncology, National University Cancer Institute, National University Health System Singapore, Singapore, Singapore, and Nawaloka Hospital Research and Education Foundation, Nawaloka Hospitals, Colombo, Sri Lanka, E-mail: wspdm199@yahoo.com. Visula Abeysuriya and Suranjith L. Seneviratne, Nawaloka Hospital Research and Education Foundation, Nawaloka Hospitals, Colombo, Sri Lanka, E-mails: visulasrilanka@hotmail.com and suran200@ yahoo.co.uk.

This is an open-access article distributed under the terms of the Creative Commons Attribution (CC-BY) License, which permits unrestricted use, distribution, and reproduction in any medium, provided the original author and source are credited.

\section{REFERENCES}

1. WHO, 2020. Coronavirus Disease (COVID-19) Situation Reports. Geneva, Switzerland: World Health Organization. Available at: https://www.who.int/emergencies/diseases/ novel-coronavirus-2019/situation-reports. Accessed November 26, 2020.

2. Jayasinghe R, Ranasinghe S, Jayarajah U, Seneviratne S, 2020. Quality of online information for the general public on COVID19. Patient Educ Couns 103: 2594-2597.

3. De Zoysa IM, Seneviratne SL, Abeysuriya V, 2020. Surgical implications of COVID-19. Int J Prog Sci Technol 21: 130-133.

4. Zhou P et al., 2020. A pneumonia outbreak associated with a new coronavirus of probable bat origin. Nature 579: 270-273.

5. Jayasekara D, Seneviratne SL, Jayasekara A, De Zoysa I, 2020. Atypical presentations of COVID-19. Adv Infect Dis 10: 136-142.

6. Borges do Nascimento IJ et al., 2020. Clinical, laboratory and radiological characteristics and outcomes of novel coronavirus (SARS-CoV-2) infection in humans: a systematic review and series of meta-analyses. PLoS One 15: e0239235.

7. Rahman A, Niloofa R, De Zoysa IM, Cooray AD, Kariyawasam J, Seneviratne SL, 2020. Neurological manifestations in COVID19: a narrative review. SAGE Open Med 8: 205031212095792.

8. Niloofa R, Seneviratne SL, Cooray A, Senanayake N, Zoysa ID, 2020. Molecular diagnosis of COVID-19. Int J Prog Sci Technol 20: 33-36.

9. Seneviratne SL, Jayarajah U, Abeysuriya V, Rahman A, Wanigasuriya K, 2020. COVID-19 vaccine landscape. J Ceylon Coll Physicians 51: 120-131.

10. Yang M, Li CK, Li K, Hon KL, Ng MH, Chan PKS, Fok TF, 2004. Hematological findings in SARS patients and possible mechanisms (review). Int $J$ Mol Med 14: 311-315.

11. Al-Tawfiq JA, Hinedi K, Abbasi S, Babiker M, Sunji A, Eltigani M, 2017. Hematologic, hepatic, and renal function changes in hospitalized patients with Middle East respiratory syndrome coronavirus. Int J Lab Hematol 39: 272-278.

12. He Z, Zhao C, Dong Q, Zhuang H, Song S, Peng G, Dwyer DE, 2005. Effects of severe acute respiratory syndrome (SARS) coronavirus infection on peripheral blood lymphocytes and their subsets. Int $J$ Infect Dis 9: 323-330.

13. Lee $\mathrm{N}$ et al., 2003. A major outbreak of severe acute respiratory syndrome in Hong Kong. N Engl J Med 348: 1986-1994.

14. Maiese A, Manetti AC, La Russa R, Di Paolo M, Turillazzi E, Frati $P$, Fineschi V, 2020. Autopsy findings in COVID-19-related deaths: a literature review. Forensic Sci Med Pathol 1-18. 
15. Giannis D, Ziogas IA, Gianni P, 2020. Coagulation disorders in coronavirus infected patients: COVID-19, SARS-CoV-1, MERS-CoV and lessons from the past. J Clin Virol 127: 104362.

16. Lippi G, Plebani M, Henry BM, 2020. Thrombocytopenia is associated with severe coronavirus disease 2019 (COVID-19) infections: a meta-analysis. Clin Chim Acta 506: 145-148.

17. Yang X, Yang Q, Wang Y, Wu Y, Xu J, Yu Y, Shang Y, 2020. Thrombocytopenia and its association with mortality in patients with COVID-19. J Thromb Haemost 18: 1469-1472.

18. Liu Y, Sun W, Guo Y, Chen L, Zhang L, Zhao S, Long D, Yu L, 2020. Association between platelet parameters and mortality in coronavirus disease 2019: retrospective cohort study. Platelets 31: $490-496$.

19. Ojha A et al., 2017. Platelet activation determines the severity of thrombocytopenia in dengue infection. Sci Rep 7: 1-10.

20. Jayarajah $U$ et al., 2018. Pattern of dengue virus infections in adult patients from Sri Lanka. Trans $R$ Soc Trop Med Hyg 112: 144-153.

21. Qu R et al., 2020. Platelet to lymphocyte ratio is associated with prognosis in patients with coronavirus disease-19. J Med Virol 92: 1533-1541.

22. Yang AP, Liu JP, Tao WQ, Li H, 2020. The diagnostic and predictive role of NLR, d-NLR and PLR in COVID-19 patients. Int Immunopharmacol 84: 106504.

23. Chan AS, Rout A, 2020. Use of neutrophil-to-lymphocyte and platelet-to-lymphocyte ratios in COVID-19. J Clin Med Res 12: 448-453.

24. Zulfiqar AA, Lorenzo-Villalba N, Hassler P, Andrès E, 2020. Immune thrombocytopenic purpura in a patient with COVID-19. N Engl J Med 382: e43.

25. Bhattacharjee S, Banerjee M, 2020. Immune thrombocytopenia secondary to COVID-19: a systematic review. SN Compr Clin Med (Epub ahead of print).

26. Li H, Wang B, Ning L, Luo Y, Xiang S, 2020. Transient appearance of EDTA dependent pseudothrombocytopenia in a patient with 2019 novel coronavirus pneumonia. Platelets 31: 825-826.

27. Kuhlman P, Nasim J, Goodman M, 2020. Panpseudothrombocytopenia in COVID-19: a harbinger for lethal arterial thrombosis? Fed Pract 37: 354-358.

28. Price LC, McCabe C, Garfield B, Wort SJ, 2020. Thrombosis and COVID-19 pneumonia: the clot thickens! Eur Respir J 56: 2001608.

29. Zhang L, Yan X, Fan Q, Liu H, Liu X, Liu Z, Zhang Z, 2020. D-dimer levels on admission to predict in-hospital mortality in patients with COVID-19. J Thromb Haemost 18: 1324-1329.

30. Klok FA et al., 2020. Incidence of thrombotic complications in critically ill ICU patients with COVID-19. Thromb Res 191: 145-147.

31. Cui S, Chen S, Li X, Liu S, Wang F, 2020. Prevalence of venous thromboembolism in patients with severe novel coronavirus pneumonia. J Thromb Haemost 18: 1421-1424.

32. Lodigiani $\mathrm{C}$ et al., 2020. Venous and arterial thromboembolic complications in COVID-19 patients admitted to an academic hospital in Milan, Italy. Thromb Res 191: 9-14.

33. Middeldorp S et al., 2020. Incidence of venous thromboembolism in hospitalized patients with COVID-19. J Thromb Haemost 18: 1995-2002.

34. Bompard F, Monnier H, Saab I, Tordjman M, Abdoul H, Fournier L, Sanchez O, Lorut C, Chassagnon G, Revel MP, 2020. Pulmonary embolism in patients with COVID-19 pneumonia. Eur Respir J 56: 2001365.

35. Helms $J$ et al., 2020. High risk of thrombosis in patients with severe SARS-CoV-2 infection: a multicenter prospective cohort study. Intensive Care Med 46: 1089-1098.

36. Jayasinghe R, Jayarajah U, Seneviratne S, 2020. Consensus on peri-operative surgical practice during the COVID-19 pandemic: an appraisal of the literature. Sri Lanka J Surg 38: 57-61.

37. Lippi G, Mattiuzzi C, 2020. Hemoglobin value may be decreased in patients with severe coronavirus disease 2019. Hematol Transfus Cell Ther 42: 116-117.

38. Wan S et al., 2020. Clinical features and treatment of COVID-19 patients in northeast Chongqing. J Med Virol 92: 797-806.

39. Wang Z, Yang B, Li Q, Wen L, Zhang R, 2020. Clinical features of 69 cases with coronavirus disease 2019 in Wuhan, China. Clin Infect Dis 71: 769-777.
40. Thomas $T$ et al., 2020. Evidence for structural protein damage and membrane lipid remodeling in red blood cells from COVID19 patients. medRxiv.

41. Huang I, Pranata R, 2020. Lymphopenia in severe coronavirus disease-2019 (COVID-19): systematic review and meta-analysis. J Intensive Care 8: 36.

42. Diao B et al., 2020. Reduction and functional exhaustion of T cells in patients with coronavirus disease 2019 (COVID-19). Front Immunol 11: 827.

43. Yan $\mathrm{X}$ et al., 2020. Neutrophil to lymphocyte ratio as prognostic and predictive factor in patients with coronavirus disease 2019: a retrospective cross sectional study. J Med Virol 92: 2573-2581.

44. Chong VCL, Lim KGE, Fan BE, Chan SSW, Ong KH, Kuperan $P$, 2020. Reactive lymphocytes in patients with COVID-19. Br J Haematol 189: 844.

45. Yip CYC, Yap ES, De Mel S, Teo WZY, Lee CT, Kan S, Lee MCC, Loh WNH, Lim EL, Lee SY, 2020. Temporal changes in immune blood cell parameters in COVID-19 infection and recovery from severe infection. Br J Haematol 190: 33-36.

46. Zhang JJ, Dong X, Cao YY, Yuan YD, Yang YB, Yan YQ, Akdis CA, Gao YD, 2020. Clinical characteristics of 140 patients infected with SARS-CoV-2 in Wuhan, China. Allergy 75: 1730-1741.

47. Zini G, Bellesi S, Ramundo F, d'Onofrio G, 2020. Morphological anomalies of circulating blood cells in COVID-19. Am J Hematol 95: 870-872.

48. Chen $\mathrm{N}$ et al., 2020. Epidemiological and clinical characteristics of 99 cases of 2019 novel coronavirus pneumonia in Wuhan, China: a descriptive study. Lancet 395: 507-513.

49. Fan BE, Chong VCL, Chan SSW, Lim GH, Lim KGE, Tan GB, Mucheli SS, Kuperan P, Ong KH, 2020. Hematologic parameters in patients with COVID-19 infection. Am J Hematol 95: E131-E134.

50. Huang $C$ et al., 2020. Clinical features of patients infected with 2019 novel coronavirus in Wuhan, China. Lancet 395: 497-506.

51. Liu W et al., 2020. Analysis of factors associated with disease outcomes in hospitalized patients with 2019 novel coronavirus disease. Chin Med J (Engl) 133: 1032-1038.

52. Qian GQ et al., 2020. Epidemiologic and clinical characteristics of 91 hospitalized patients with COVID-19 in Zhejiang, China: a retrospective, multi-centre case series. QJM 113: 474-481.

53. Qin $C$ et al., 2020. Dysregulation of immune response in patients with coronavirus 2019 (COVID-19) in Wuhan, China. Clin Infect Dis 71: 762-768.

54. Ruan Q, Yang K, Wang W, Jiang L, Song J, 2020. Clinical predictors of mortality due to COVID-19 based on an analysis of data of 150 patients from Wuhan, China. Intensive Care Med 46: 846-848.

55. Wang D et al., 2020. Clinical characteristics of 138 hospitalized patients with 2019 novel coronavirus-infected pneumonia in Wuhan, China. JAMA 323: 1061-1069.

56. Wu C et al., 2020. Risk factors associated with acute respiratory distress syndrome and death in patients with coronavirus disease 2019 pneumonia in Wuhan, China. JAMA Intern Med 180: 934-943.

57. $\mathrm{Xu} X$ et al., 2020. Imaging and clinical features of patients with 2019 novel coronavirus SARS-CoV-2. Eur J Nucl Med Mol Imaging 47: 1275-1280.

58. Yang $X$ et al., 2020. Clinical course and outcomes of critically ill patients with SARS-CoV-2 pneumonia in Wuhan, China: a single-centered, retrospective, observational study. Lancet Respir Med 8: 475-481.

59. Zachariah $P$ et al., 2020. Epidemiology, clinical features, and disease severity in patients with coronavirus disease 2019 (COVID-19) in a children's hospital in New York city, New York. JAMA Pediatr 174: 202430.

60. Zhang JJ, Dong X, Cao YY, Yuan YD, Yang YB, Yan YQ, Akdis CA, Gao YD, 2020. Clinical characteristics of 140 patients infected with SARS-CoV-2 in Wuhan, China. Allergy 75: 1730-1741.

61. Zhou F et al., 2020. Clinical course and risk factors for mortality of adult inpatients with COVID-19 in Wuhan, China: a retrospective cohort study. Lancet 395: 1054-1062. 
62. Debliquis A, Harzallah I, Mootien JY, Poidevin A, Labro G, Mejri A, Lamarque M, Kuteifan K, Drénou B, 2020. Haemophagocytosis in bone marrow aspirates in patients with COVID-19. Br J Haematol 190: e70-e73.

63. Rapkiewicz AV et al., 2020. Megakaryocytes and platelet-fibrin thrombi characterize multi-organ thrombosis at autopsy in COVID-19: a case series. EClinicalMedicine 24: 100434.

64. Hamming I, Timens W, Bulthuis MLC, Lely AT, Navis GJ, van Goor H, 2004. Tissue distribution of ACE2 protein, the functional receptor for SARS coronavirus. A first step in understanding SARS pathogenesis. J Pathol 203: 631-637.

65. Feng Z et al., 2020. The novel severe acute respiratory syndrome coronavirus 2 (SARS-CoV-2) directly decimates human spleens and lymph nodes running title: SARS-CoV-2 infects human spleens and lymph nodes. medRxiv. Preprint 2020 March 27.

66. Xu X, Chang XN, Pan HX, Su H, Huang B, Yang M, Luo DJ, Weng MX, Ma L, NieX, 2020. Pathological changes of the spleen in ten patients with new coronavirus infection by minimally invasive autopsies. Chin J Pathol 49: E014.

67. Yao XH et al., 2020. A pathological report of three COVID-19 cases by minimally invasive autopsies. Chin J Pathol 49: E009.

68. Santos Leite Pessoa M, Franco Costa Lima C, Farias Pimentel AC, Godeiro Costa JC, Bezerra Holanda JL, 2020. Multisystemic infarctions in COVID-19: focus on the spleen. Eur $J$ Case Rep Intern Med 7: 001747.

69. Chen $Y$ et al., 2020. The novel severe acute respiratory syndrome coronavirus 2 (SARS-CoV-2) directly decimates human spleens and lymph nodes. medRxiv (Epub ahead of print).

70. Li MY, Li L, Zhang Y, Wang XS, 2020. Expression of the SARSCoV-2 cell receptor gene ACE2 in a wide variety of human tissues. Infect Dis Poverty 9: 45.

71. Xu X, Chang XN, Pan HX, Su H, Huang B, Yang M, Luo DJ, Weng MX, Ma L, NieX, 2020. Pathological changes of the spleen in ten patients with coronavirus disease 2019(COVID-19) by postmortem needle autopsy. Chin J Pathol 49: 576-582.

72. Ratajczak MZ, Kucia M, 2020. SARS-CoV-2 infection and overactivation of Nirp3 inflammasome as a trigger of cytokine "storm" and risk factor for damage of hematopoietic stem cells. Leukemia 34: 1726-1729.

73. Joshi S, Balasubramanian N, Vasam G, Jarajapu YPR, 2016. Angiotensin converting enzyme versus angiotensin converting enzyme-2 selectivity of MLN-4760 and DX600 in human and murine bone marrow-derived cells. Eur J Pharmacol 774: 25-33.

74. Xu P, Zhou Q, Xu J, 2020. Mechanism of thrombocytopenia in COVID-19 patients. Ann Hematol 99: 1205-1208.

75. Nardi M, Tomlinson S, Greco MA, Karpatkin S, 2001. Complement-independent, peroxide-induced antibody lysis of platelets in HIV-1-related immune thrombocytopenia. Cell 106: 551-561.

76. Hindilerden F, Yonal-Hindilerden I, Sevtap S, Kart-Yasar K, 2020. Immune thrombocytopenia in a very elderly patient with covid-19. Front Med 7: 404.

77. Hu Z, Chen W, Liang W, Xu C, Sun W, Yi Y, 2020. Severe exacerbation of immune thrombocytopenia and COVID-19: the favorable response to corticosteroid-based therapy-a case report. Ann Hematol (Epub ahead of print 2020 Jun 4).

78. Humbert S, Razanamahery J, Payet-Revest C, Bouiller K, Chirouze C, 2020. COVID-19 as a cause of immune thrombocytopenia. Med Mal Infect 50: 459-460.

79. Zhang W, Nardi MA, Borkowsky W, Li Z, Karpatkin S, 2009. Role of molecular mimicry of hepatitis $C$ virus protein with platelet GPIIla in hepatitis C-related immunologic thrombocytopenia. Blood 113: 4086-4093.

80. Escher R, Breakey N, Lämmle B, 2020. Severe COVID-19 infection associated with endothelial activation. Thromb Res 190: 62.

81. He L et al., 2020. Pericyte-specific vascular expression of SARSCoV-2 receptor ACE2 - implications for microvascular inflammation and hypercoagulopathy in COVID-19 patients. bioRxiv (Epub ahead of print).

82. Barnes BJ et al., 2020. Targeting potential drivers of COVID-19: neutrophil extracellular traps. J Exp Med 217: e20200652.
83. Fletcher-Sandersjöö A, Bellander BM, 2020. Is COVID-19 associated thrombosis caused by overactivation of the complement cascade? A literature review. Thromb Res 194: 36-41.

84. Liu W, Li H, 2020. COVID-19: attacks the 1-beta chain of hemoglobin and captures the porphyrin to inhibit human heme metabolism. ChemRxiv. Preprint. DOI: https://doi.org/10.26434/ chemrxiv.11938173.v9.

85. Xu H, Zhong L, Deng J, Peng J, Dan H, Zeng X, Li T, Chen Q, 2020. High expression of ACE2 receptor of 2019-nCoV on the epithelial cells of oral mucosa. Int J Oral Sci 12: 8 .

86. Tan L, Wang Q, Zhang D, Ding J, Huang Q, Tang YQ, Wang Q, Miao H, 2020. Lymphopenia predicts disease severity of COVID-19: a descriptive and predictive study. Signal Transduct Target Ther 5: 1-3.

87. Park TS, Zambidis ET, 2009. A role for the renin-angiotensin system in hematopoiesis. Haematologica 94: 745-747.

88. Jarajapu YP, 2020. Targeting ACE2/angiotensin-(1-7)/mas receptor axis in the vascular progenitor cells for cardiovascular diseases. Mol Pharmacol 99: 29-38.

89. Akkina R, 2013. New insights into HIV impact on hematopoiesis. Blood 122: 2144-2146.

90. Chowdhury SF, Anwar S, 2020. Management of hemoglobin disorders during the COVID-19 pandemic. Front Med 7: 306.

91. Motta I et al., 2020. SARS-CoV-2 infection in beta thalassemia: preliminary data from the Italian experience. Am J Hematol 95: E198-E199.

92. Lansiaux E, Pébaÿ PP, Picard JL, Son-Forget J, 2020. COVID19: beta-thalassemia subjects immunised? Med Hypotheses 142: 109827.

93. Dongyan C, Ai Z, Aiguo L, Qun H, 2020. Clinical findings in a patient with hemophilia A affected by COVID-19. Haemophilia 26: e214-e216.

94. Rubinstein SM, Warner JL, 2020. COVID-19 and haematological malignancy: navigating a narrow strait. Lancet Haematol 7: e701-e703.

95. Willan J, King AJ, Hayes S, Collins GP, Peniket A, 2020. Care of haematology patients in a COVID-19 epidemic. Br J Haematol 189: 241-243.

96. Passamonti F et al., 2020. Clinical characteristics and risk factors associated with COVID-19 severity in patients with haematological malignancies in Italy: a retrospective, multicentre, cohort study. Lancet Haematol 7: e737-e745.

97. He W et al., 2020. COVID-19 in persons with haematological cancers. Leukemia 34: 1637-1645.

98. Dai M et al., 2020. Patients with cancer appear more vulnerable to SARS-CoV-2: a multicenter study during the COVID-19 outbreak. Cancer Discov 10: 783-791.

99. Piñana JL et al., 2020. Risk factors and outcome of COVID-19 in patients with hematological malignancies. Exp Hematol Oncol 9: 21

100. Garciá-Suárez J et al., 2020. Impact of hematologic malignancy and type of cancer therapy on COVID-19 severity and mortality: lessons from a large population-based registry study. $J$ Hematol Oncol 13: 133

101. Lattenist R, Yildiz H, De Greef J, Bailly S, Yombi JC, 2020. COVID-19 in adult patients with hematological disease: analysis of clinical characteristics and outcomes. Indian J Hematol Blood Transfus (Epub ahead of print).

102. Giannakoulis VG, Papoutsi E, Siempos II, 2020. Effect of cancer on clinical outcomes of patients with COVID-19: a metaanalysis of patient data. JCO Glob Oncol 6: 799-808.

103. Schrag D, Hershman DL, Basch E, 2020. Oncology practice during the COVID-19 pandemic. J Am Med Assoc 323: 2005-2006.

104. Shirke MM, Shaikh SA, Harky A, 2020. Implications of telemedicine in oncology during the COVID-19 pandemic. Acta Biomed 91: 1-7.

105. Al Shamsi HO et al., 2020. A practical approach to the management of cancer patients during the novel coronavirus disease 2019 (COVID-19) pandemic: an International Collaborative Group. Oncologist 25: e936-e945.

106. Sternberg $C$ et al., 2020. Oncology practice during COVID-19 pandemic: a fast response is the best response. Rev Assoc Med Bras 66: 338-344. 
107. Lara Gongoria AB, Fontes Jardim DL, Bastos DA, 2020. Oncology clinical trials during the COVID-19 pandemic. Oncology Williston Park) 34: 265-269.

108. Madan A, Siglin J, Khan A, 2020. Comprehensive review of implications of COVID-19 on clinical outcomes of cancer patients and management of solid tumors during the pandemic. Cancer Med 9: 9205-9218.

109. Malard $\mathrm{F}$ et al., 2020. COVID-19 outcomes in patients with hematologic disease. Bone Marrow Transplant 55: 2180-2184.

110. Lee LYW, Cazier JB, Starkey T, Turnbull CD; UK Coronavirus Cancer Monitoring Project Team, Kerr R, Middleton G, 2020. COVID-19 mortality in patients with cancer on chemotherapy or other anticancer treatments: a prospective cohort study. Lancet (London, England) 395: 1919-1926.

111. The Severe COVID-19 GWAS Group, 2020. Genomewide association study of severe COVID-19 with respiratory failure. N Engl J Med 383: 1522-1534.

112. Stanworth SJ et al., 2020. Effects of the COVID-19 pandemic on supply and use of blood for transfusion. Lancet Haematol 7: e756-e764.

113. Barriteau CM, Bochey P, Lindholm PF, Hartman K, Sumugod R, Ramsey G, 2020. Blood transfusion utilization in hospitalized COVID-19 patients. Transfusion 60: 1919-1923.

114. Corman VM, Rabenau HF, Adams O, Oberle D, Funk MB, KellerStanislawski B, Timm J, Drosten C, Ciesek S, 2020. SARSCoV-2 asymptomatic and symptomatic patients and risk for transfusion transmission. Transfusion 60: 1119-1122.

115. Albiol N, Awol R, Martino R, 2020. Autoimmune thrombotic thrombocytopenic purpura (TTP) associated with COVID-19. Ann Hematol 99: 1673-1674.

116. Hindilerden F, Yonal-Hindilerden I, Akar E, Kart-Yasar K, 2020. COVID-19 associated autoimmune thrombotic thrombocytopenic purpura: report of a case. Thromb Res 195: 136-138.

117. Kreuziger LB, Lee A, Garcia D, Cuker A, Cushman M, DeSancho M, Connors JM, 2020. COVID-19 and VTE-anticoagulation. Washington, DC: American Society of Hematology. Available at: https://www.hematology.org/covid-19/covid-19-and-vteanticoagulation. Accessed November 26, 2020.

118. Poterucha TJ, Libby P, Goldhaber SZ, 2017. More than an anticoagulant: do heparins have direct anti-inflammatory effects? Thromb Haemost 117: 437-444.

119. Wang TF, Milligan PE, Wong CA, Deal EN, Thoelke MS, Gage BF, 2013. Efficacy and safety of high-dose thromboprophylaxis in morbidly obese inpatients. Thromb Haemost 111: 88-93.

120. Roberts LN, Whyte MB, Georgiou L, Giron G, Czuprynska J, Rea C, Vadher B, Patel RK, Gee E, Arya R, 2020. Postdischarge venous thromboembolism following hospital admission with COVID-19. Blood 136: 1347-1350.

121. Hajra A, Mathai SV, Ball S, Bandyopadhyay D, Veyseh M, Chakraborty S, Lavie CJ, Aronow WS, 2020. Management of thrombotic complications in COVID-19: an update. Drugs 80: 1553-1562.

122. Tang N, Bai H, Chen X, Gong J, Li D, Sun Z, 2020. Anticoagulant treatment is associated with decreased mortality in severe coronavirus disease 2019 patients with coagulopathy. J Thromb Haemost 18: 1094-1099.

123. White $D$ et al., 2020. Heparin resistance in COVID-19 patients in the intensive care unit. J Thromb Thrombolysis 50: 287-291.

124. Fischer EA, Kinnear B, Sall D, Kelleher M, Sanchez O, Mathews B, Schnobrich D, Olson APJ, 2019. Hospitalist-operated compression ultrasonography: a point-of-care ultrasound study (HOCUS-POCUS). J Gen Intern Med 34: 2062-2067.
125. Testa S, Paoletti O, Giorgi-Pierfranceschi M, Pan A, 2020. Switch from oral anticoagulants to parenteral heparin in SARSCoV-2 hospitalized patients. Intern Emerg Med 15: 751-753.

126. Thachil J, Tang N, Gando S, Falanga A, Levi M, Clark C, Iba T, Cattaneo M, 2020. Type and dose of heparin in covid-19: reply. J Thromb Haemost 18: 2063-2064.

127. Artifoni M, Danic G, Gautier G, Gicquel P, Boutoille D, Raffi F, Néel $A$, Lecomte R, 2020. Systematic assessment of venous thromboembolism in COVID-19 patients receiving thromboprophylaxis: incidence and role of D-dimer as predictive factors. J Thromb Thrombolysis 50: 211-216.

128. Demelo-Rodríguez $P$ et al., 2020. Incidence of asymptomatic deep vein thrombosis in patients with COVID-19 pneumonia and elevated D-dimer levels. Thromb Res 192: 23-26.

129. Léonard-Lorant I et al., 2020. Acute pulmonary embolism in patients with COVID-19 at CT angiography and relationship to d-dimer levels. Radiology 296: E189-E191.

130. Llitjos JF, Leclerc M, Chochois C, Monsallier JM, Ramakers M, Auvray M, Merouani K, 2020. High incidence of venous thromboembolic events in anticoagulated severe COVID-19 patients. J Thromb Haemost 18: 1743-1746.

131. Maatman TK et al., 2020. Routine venous thromboembolism prophylaxis may be inadequate in the hypercoagulable state of severe coronavirus disease 2019. Crit Care Med 48: E783-E790.

132. Poissy J, Goutay J, Caplan M, Parmentier E, Duburcq T, Lassalle F, Jeanpierre E, Rauch A, Labreuche J, Susen S, 2020. Pulmonary embolism in patients with COVID-19: awareness of an increased prevalence. Circulation 142: 184-186.

133. Zhang $L$ et al., 2020. Deep vein thrombosis in hospitalized patients with COVID-19 in Wuhan, China: prevalence, risk factors, and outcome. Circulation 142: 114-128.

134. Horby $P$ et al., 2020. Effect of dexamethasone in hospitalized patients with COVID-19: preliminary report. medRxiv (Epub ahead of print).

135. Leng $Z$ et al., 2020. Transplantation of ACE2- mesenchymal stem cells improves the outcome of patients with COVID-19 pneumonia. Aging Dis 11: 216-228.

136. Rajendran D, Narayanasamy D, Rangarajan D, Rathinam D, Natarajan D, Ramachandran D, 2020. Convalescent plasma transfusion for the treatment of COVID-19: systematic review. J Med Virol 92: 1475-1483.

137. Salazar E et al., 2020. Treatment of coronavirus disease 2019 patients with convalescent plasma reveals a signal of significantly decreased mortality. Am J Pathol 190: 2290-2303.

138. Li L et al., 2020. Effect of convalescent plasma therapy on time to clinical improvement in patients with severe and lifethreatening COVID-19: a randomized clinical trial. JAMA 324: 460-470.

139. Abraham J, 2020. Passive antibody therapy in COVID-19. Nat Rev Immunol 20: 401-403.

140. Seneviratne SL, Niloofa R, De Zoysa I, de Mel S, Abeysuriya V, 2020. Remdesivir and COVID-19. Int J Adv Res 8: 565-567.

141. Seneviratne SL, Abeysuriya V, De Mel S, Zoysa ID, Niloofa R, 2020. Favipiravir in COVID-19. Int J Prog Sci Technol 19: 143-145.

142. Singh AK, Singh A, Singh R, Misra A, 2020. Remdesivir in COVID19: a critical review of pharmacology, pre-clinical and clinical studies. Diabetes Metab Syndr Clin Res Rev 14: 641-648.

143. Borges do Nascimento IJ, Cacic N, Abdulazeem HM, von Groote TC, Jayarajah U, Weerasekara I, Esfahani MA, Civile VT, Marusic A, Jeroncic A, 2020. Novel coronavirus infection (COVID-19) in humans: a scoping review and meta-analysis. J Clin Med 9: 941.

144. Yao $Y$ et al., 2020. D-dimer as a biomarker for disease severity and mortality in COVID-19 patients: a case control study. J Intensive Care 8: 49. 